\title{
Adulticide Efficacy of Artemisia vulgaris L. against Aedes aegypti L.
}

\author{
Potensi Adultisida dari Artemia vulgaris L. terhadap Aedesagypti L. \\ Vika Ichsania Ninditya ${ }^{1 *}$, Endah Purwati ${ }^{1}$, Ajeng Tyas Utami ${ }^{1}$, Aprillyani Sofa Marwaningtyaz ${ }^{2}$, \\ Nadia Khairunnisa Fairuz ${ }^{2}$, Penny Humaidah Hamid ${ }^{3}$ \\ ${ }^{1}$ Faculty of Veterinary Medicine, Universitas Gadjah Mada \\ ${ }^{2}$ Faculty of Pharmacy, Universitas Gadjah Mada \\ ${ }^{3}$ Department of Parasitology, Veterinary Medicine, Universitas Gadjah Mada \\ *E-mail: vika.ichsania.n@mail.ugm.ac.id
}

\begin{abstract}
Aedes aegypti is the vector of various arthropod-borne diseases such as dengue fever, chikungunya and currently, zika. This study aimed to evaluate Artemisia vulgarisas other adulticides for controlling Ae. aegypti. Indonesian ministry of health hasbeen reported that more than 70.000 dengue fever human cases have occurred in 2015 covering 34 provinces which mean that dengue fever has spread now into all national territories. Eradication of Aedes still largely depends on insecticides, which is the most cost-effective strategy, and often inefficient due to resistance development in exposed Aedes population This study was designed to use of Centers for Disease Control and Prevention (CDC) bioassay standard. CDC bottles were coated with the ethanolic solution of extract with a concentration of 10, 50, 100, 500,1000, 5000, 10000, 50000, and $100000 \mu \mathrm{g}$ per bottle. F0 mosquitoes were used for all experiments. Death and surviving mosquitoes were evaluated based on CDC standard assay. The test was performed with 10-25 adult mosquitoes every bottle and each concentration was repeated in triplicates. The results showed that $\mathrm{LC}_{50}$ and $\mathrm{LC}_{90}$ were $5790 \mu \mathrm{g}$ and $52110 \mu \mathrm{g}$ respectively after 120 minutes exposure to the extract. There was no mortality in ethanol control group. A. vulgaris significantly $(\mathrm{P}<0.05)$ have adulticidal activity against Ae. aegypti. However, A. vulgaris have been reported to have larvacidal activity against Ae. Aegypti. These results indicated clearly that $A$. Vulgaris might act as the candidate of bioinsecticides for controlling Ae. aegypti.
\end{abstract}

Keywords: Aedes aegypti, Artemisia vulgaris, adulticide, bio insecticide.

\section{INTRODUCTION}

Mosquitoes are the vector of various disease such as malaria, chikungunya, dengue fever, yellow fever, Japanese encephalitis, filariasis, schistosomiasis and currently zika (Govindarajan et al., 2011). There are 111 genera and 137 subgenera containing 3,517 species of mosquitoes in worldwide (Becker et al., 2010). Aedes aegypti is a major vector of arthropod-borne disease, primary vector responsible for dengue fever, yellow fever, chikungunya, and Zika fever (Ajaegbu et al., 2016). Dengue is major public health problem globally (Samuel \& Tyagi, 2006) over 3.97 billion people in 128 countries at risk of disease. At 2010 approximately there were 390 million cases (Sayono et al., 2016). Indonesian ministry of health has been reported that more than 70.000 dengue fever human cases have occurred in 2015 covering 34 provinces which mean that dengue fever has spread now into all national territories(Hamid et al., 2017). While vaccine of dengue fever is still developing with active research, the only way to prevent and control dengue virus transmission by controlling the vector (Wuliandari et al., 2015, Elumalai et al., 2016). The application of chemical and synthetic insecticide has been long utilized, there were several problems such as insecticidal resistance, environmental pollution, and harmful impact on human and other organisms (Cheah et al., 2013).

Mosquitoes have been resistance to synthetic and chemical insecticide in several places in Indonesia, as in Central Java province (Sayono et al., 2016), Yogyakarta province (Wuliandari et al., 2015), Bali (Hamid et al., 2017), Bandung, Surabaya, Palembang (Ahmad et al., 2007), and East Jakarta (Hardjanti et al., 2015). Therefore, a new strategy of controlling mosquitoes need to develop. It has prompted the researcher to look for environment-friendly, safe for human and animal, target specific for mosquitoes, and cost effective. Another control method such as botanical and microbial insecticide has been applied for last few year (Elumalai et al., 2016). Due to limited use of it in vector control programs, no study reported about resistance. 
Plant extract may be alternative source due to it has the abundant bioactive compound. Artemisia vulgaris is the member of the family of Asteraceae. A. vulgaris has height about 11.5 meter and release aromatic fragrant. Artemisia distributed throughout the northern temperate regions of Africa, Europe, Asia, and North America. The chemical studies on $A$. vulgaris indicate that thujone isomer and camphor were determined as the main components in A. Vulgaris from India (Judžentienė \& Buzelyte 2006). Compounds like terpenoids and flavonoids are present in this plant. Artemisia extracts also contain artemisinin that has been reported to reduce Plasmodium falciparum gametocyte development, thus reducing transmission of malaria, this fact significant in preventing the spread of resistant strain (Masotti et al., 2012). However, to our knowledge, the mosquito adulticidal activity of $A$. vulgaris extract has been little investigated.

\section{METHODS}

\section{Plant collection}

The plant $A$. vulgaris were collected from Tlahap, Kledung, Temanggung, Central Java ( $7^{\circ} 19^{\prime} 30^{\prime}$ S and $110^{\circ} 14^{\prime} 88^{\prime}$ E) in March 2017. Taxonomic identification was issued by Department of Plant Systematic, Biology Faculty, Universitas Gadjah Mada, Yogyakarta, Indonesia.

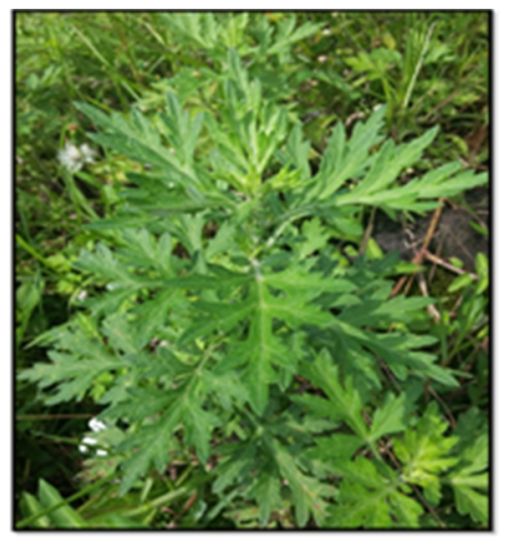

Figure 1. Artemisia vulgaris from Tlahap, Kledung, Temanggung, Central Java

\section{Mosquitoes rearing}

The eggs of Ae. Aegypti was collected using about 200 ovitraps in several places in Sleman, Yogyakarta. Eggs were transferred to laboratory Parasitology, Faculty of Veterinary Medicine, Universitas Gadjah Mada. Eggs were hatched using plastic container $20 \times 15 \times 5 \mathrm{~cm} 3$ filled with $800 \mathrm{ml}$ tap water within \pm 24 hours. Larvae were fed with chicken liver and maintained at $28^{\circ} \mathrm{C}, 70-85 \%$ relative humidity, with a photoperiod of $14 \mathrm{~h}$ light and ten $\mathrm{h}$ dark. Pupae were transferred to a cup (12 $\mathrm{cm} \times$ diameter $9.8 \mathrm{~cm}$ ) containing $200 \mathrm{ml}$ clean water covered with a net for adult emergence. The adult was moved into the cage $(20 \times 20 \times 20 \mathrm{~cm})$ and fed using $10 \%$ sucrose solution soaked in cotton.

\section{Extraction}

A total of 5 kilograms A. vulgaris were cleaned and dried using the oven for seven days with temperature $55^{\circ} \mathrm{C}$.Total 300 grams dried leaves were grounded into powder by grinding machine. Ethanol $95 \%$ (Emsure, Germany) was added to the powder for $A$. Vulgarismaceration. The mixture of $A$ vulgarisand ethanol is homogenized for 30 minutes and kept for one day at room temperature. Complete removal of the filtrate was accomplished in vacuum rotary evaporator. The extract then is heated in the water bath at a temperature of $70^{\circ} \mathrm{C}$. The final extract was in the pasta form and kept in $4^{\circ} \mathrm{C}$ until further use.

Adulticidal test using Center for Diseases Control Prevention (CDC) Standard

Weighing one gram of extract dissolved in $100 \mathrm{ml}$ of ethanol for making $1 \%$ of the stock solution. To make 10, 50, 100, 500, 1000, 5000, 10000, 50000, and $100000 \mu \mathrm{g}$ per bottle. Stock solution diluted using ethanol and transferred to a bottle according to the concentration required. The bottle used has a volume of $250 \mathrm{ml}$, the bottle was washed using soapy water then rinsed three times and placed in an oven for 20 minutes until dry. One $\mathrm{ml}$ of each concentration solution added to the bottle including for control using only ethanol; the bottle rotated gently to make all side coated with the solution, the caps were removed and continuously rolled until the solution completely dry. The bottle was kept from direct sunlight.

\section{Bioassay procedure}

The assay was performed using 10-25 F0 mosquitoes (2-5 days old sucrose fed) put into the previous bottle using the aspirator. Every 15 minutes the mosquitoes were observed until two hours long. Mosquitoes were considered died if they could no longer stand, the dead and alive mosquitoes were recorded. This procedure was performed triplicates include the control.

\section{Statistical analysis}

The average mortality was subjected to ANOVA using GraphPad Prism 7.00 and probit analysis for calculating lethal dosages causing $50 \%$ and $90 \%$ mortality (LC50 and LC90) also 95\% upper and lower confidence limit.

\section{RESULTS AND DISCUSSION}

The adulticidal activity of $A$. vulgaris in the ethanolic extract at various concentration against Ae. aegyptiwas illustrated in figure 2. Observation of present study showed that mortality was increased as the concentration increased in 90, 105 and 120 minutes. For example in $100 \mathrm{mg}$ concentration, mortality 
was measured $6,7 \%$ and increased to $15 \%$ at $500 \mu \mathrm{g}$ in 120 minutes. $100 \%$ mortality was reached at $10000 \mu \mathrm{g}$. The LC50 and LC90 were determined by using probit analysis (GraphPad Prism 7.0.). The results given in figure 3 showed that LC50 and LC90 were $5790 \mu \mathrm{g}$ and $52110 \mu \mathrm{g}$ respectively after 120 minutes exposure to the extract. The $95 \%$ lower confidence limit is $3331 \mu \mathrm{g}$ and upper confidence limit is $9961 \mu \mathrm{g}$. There was no mortality in ethanol control group. A. vulgaris significantly $(\mathrm{P}<0.05)$ have adulticidal activity against Ae. aegypti.

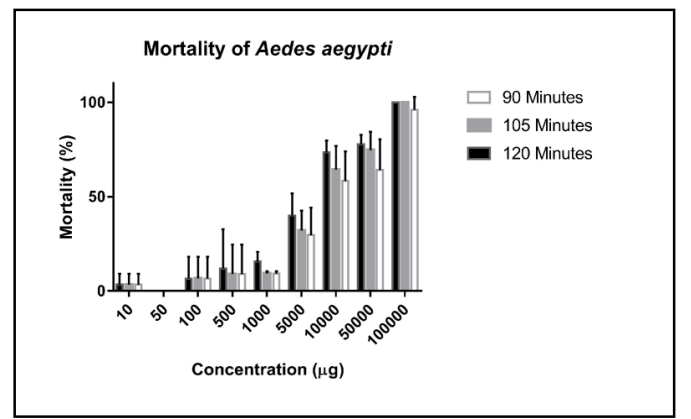

Figure 2. Adulticidal activity of $A$. vulgaris extract against Ae. aegypti.

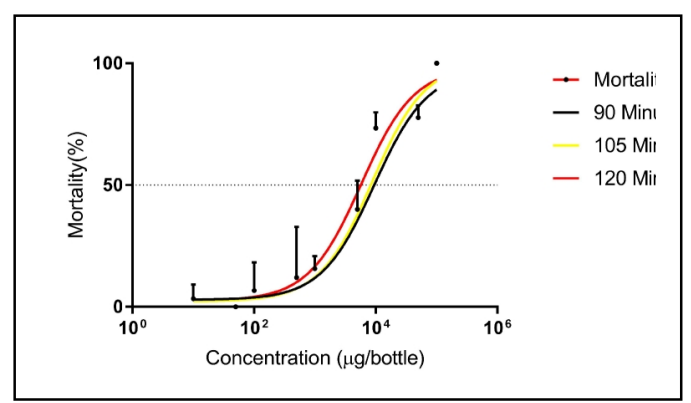

Figure 3. Graph showed result of probit analysis

Insecticides resistance tends to increase worldwide (Hamid et al,. 2017, Ishak et al. ,2015, Li et al., 2015, Lima et al., 2011, Saavedra et al,. 2007). This problem becomes a dangerous nowadays since arthropod-borne diseases prevention strategy depends on the vector controls. Compounds from natural herb can be used as an alternative insecticide to control the vectors (Govindarajan et al., 2011). Bioinsecticide of plant origin was used against several insect species due to safer to human, without toxic and no residues left in the environment.

The adulticide assay of this study showed activity against adult Ae. aegypti. We adapted CDC bottle assay in this experiment to demonstrate the ability of $A$. vulgaris in penetrating adult Ae. aegypti and killing the mosquitoes. According to literature survey, lack of published paper about the adulticidal activity of $A$. vulgaris on Ae. aegypti. However, A. vulgaris have been reported to have larvacidal activity against Ae. Aegypti (Mya et al., 2016, Sundararajan \& Kumari, 2017). Another species of Artemisia, $A$. nilagirica have been reported to have adulticidal activity against Ae. aegypti (Panneerselvam et al., 2012) indicated that $A$. nilagirica has adulticide activity the LC50 and LC90 values 242.52 and 523.73 ppm. A. апnиa in the previous report showed that have larvacidal activity, ovicidal and oviposition deterrent (Cheah et al., 2013), A. abrotanum and $A$. pontica also showed have larvacidal activity (Tabanca et al., 2011). Using Spondia mombin leaves in methanol extract (Ajaegbu et al., 2016) with CDC bioassay procedure showed the LC50 values of $4061.946 \mu \mathrm{g} / \mathrm{bottle}$ in 24 hours post treatment. Ae. aegypti showed restless movement, abnormal wagging, and died inside the bottle contain A. vulgaris extract only within 120 minutes.

Another plant has adulticidal activity using WHO protocol, essential oil Piper retrofractum Vahl in acetone showed that LD50 and LD99 of against Ae. aegypti $(8.86 \%, 23.21 \%)$ and Culex quinquefasciatus $(6.95 \%$ and $17.35 \%)$ (Subsuebwonget al., 2016).

Cassiatora leaf extracts against the adulticidal activity of (hexane, chloroform benzene, acetone, and methanol) Ae. aegyptiLC(50) values were 329.82, 307.31, 287.15, 269.57, and $252.03 \mathrm{ppm}$ and LC(90) values were 563.24, 528.33, 496.92, 477.61, and 448.05 ppm (Amerasanet al. 2012). Citrus sinensis orange peel extract against $\mathrm{Ae}$. aegypti showed LC50 value was $320.38 \mathrm{ppm}$ (Muruganet al., 2012). Clausena dentata plant extract against Ae. aegypti showed the LC50 and LC90 $4.1783 \mathrm{mg} / \mathrm{ml}$ and $9.3884 \mathrm{mg} / \mathrm{ml}$ (Ramkumar et al., 2015). The obtained results indicate that the extract of $A$. vulgaris has potential to be developed as an adulticide against Ae. aegypti mosquitoes. However, further studies to evaluate its toxicity need to be conducted. Studies aimed at isolation andidentification of active compounds must be performed. The results of the present study could be used in promoting research aimed at the development of new agents for mosquito 
control based on bioactive chemical compounds from indigenous plant sources.

\section{CONCLUSION}

The results indicate that the extract of $A$. vulgaris has potential to be developed as an adulticide against Ae. aegypti mosquitoes with LC50 and LC90 were $5790 \mathrm{mg}$ and $52110 \mathrm{mg}$. However, further studies to evaluate its toxicity need to be conducted.

\section{ACKNOWLEDGEMENT}

This study was funded by Student Creativity Program and partially funded by INSINAS grant no. 226/SP2H/LT/DRPM/III/2016 by Ministry of Research, Technology, and Higher Education of the Republic of Indonesia.

\section{REFERENCES}

Ahmad I., Astari S, \& Tan M. 2007. Resistance of Aedes aegypti in 2006 to Pyrethroid Insecticide in Indonesia and its Association with Oxidase and Esterase Levels. Pakistan Journal of Biological Science. 10: 36883692.

Ajaegbu EE., Danga SP, Chijoke IU, \& Okoye FB. 2016. Mosquito Adulticidal Activity of the Leaf Extracts of Spondiasmombin L. against Aedesaegypti L. and Isolation of Active Principles. $J$ Vector Borne Dis. 53: 17-22.

Amerasan D, Murugan K, Kovendan K, Mahesh-Kumar P, Panneerselvam C, Subramaniam J, William SJ, Hwang JS. 2012. Adulticidal and Repellent Properties of Cassia tora Linn. (Family: Caesalpinaceae) against Culexquinque fasciatus, Aedesaegypti, and Anopheles stephensi.Parasitol Res, 111: 1953-64.

Becker N, Petric D, Zgomba M, Boase C, Dahl C, \& Madon M. 2010. Mosquitoes and Their Control. Berlin Heidelberg: Springer.

Cheah SX, Tay JW, Chan LK \& Jaa 1Z. 2013. Larvicidal, Oviposition, and Ovicidal Effects of Artemisia Annua (Asterales: Asteraceae) against Aedesaegypti, Anopheles sinensis, and Culexquinque fasciatus (Diptera: Culicidae). Parasitology Research.112: 3275-3282.

Elumalai D, Hemavathi M, Hemalatha P, Deepaa CV \& Kaleena PK. 2016. Larvicidal Activity of Catechin Isolated from Leucasaspera againstAedes aegypti, Anopheles stephensi, and Culexquinque fasciatus (Diptera: Culicidae). Parasitology
Research. 115: 1203-1212.

Govindarajan M, Mathivanan T, Elumalai K,. Krishnappa K \& Anandan A. 2011. Mosquito larvicidal, ovicidal, and repellent properties of botanical extracts against Anopheles stephensi, Aedesaegypti, and Culexquinque fasciatus (Diptera: Culicidae). Parasitology Research. 109: 353-367.

Hamid PH, Prastowo J, Widyasari A, Taubert A \& Hermosilla C. 2017. Knockdown resistance $(\mathrm{kdr})$ of the voltage-gated sodium channel gene of Aedesaegypti population in Denpasar, Bali, Indonesia. Parasites \& Vectors, 10: 238.

Hardjanti A, Indrawati I, Donanti E, Wibowo H \& Zulhasril Z. 2015. Detection of Insecticide Resistance in Aedesaegypti to Organophosphate in Pulogadung, East Jakarta. Makara J. Health Res.19:117-120.

Ishak IH, Jaal Z, Ranson H \& Wondji CS.2015. Contrasting patterns of insecticide resistance and knockdown resistance (kdr) in the dengue vectors Aedesaegypti and Aedesalbopictus from Malaysia. Parasit Vectors. 8: 181.

Judžentienė A \& Buzelyte J. 2006. Chemical composition of essential oils of Artemisia vulgaris L. (mugwort) from North Lithuania. CHEMIJA. 17: 12-15.

Saavedra-Rodriguez K, Urdaneta-Marquez L., Rajatileka S., Moulton M., Flores AE., Fernandez-Salas I., Bisset J, Rodriguez M, McCall PJ, Donnelly MJ, Ranson H, Hemingway J, Black WC. 2007. A Mutation in The Voltage-gated Sodium Channel Gene Associated with Pyrethroid Resistance in Latin American Aedesaegypti. Insect Mol Biol. 16: 785-98.

Li CX, Kaufman PE., XueR D,. Zhao MH, Wang G, Yan T, Guo XX,. ZhangY M,. Dong YD, Xing D,. Zhang HD, Zhao TY. 2015. Relationship Between Insecticide Resistance and kdr Mutations in The Dengue Vector Aedesaegypti in Southern China. Parasites \& Vectors. 8: 325.

Lima EP, Paiva MH, de Araujo AP, da Silva E $\mathrm{V}$, da Silva UM, de Oliveira LN, Santana $\mathrm{AE}$, Barbosa $\mathrm{CN}$, de Paiva Neto $\mathrm{CC}$, Goulart MO, Wilding CS, Ayres CF, de Melo Santos MA. 2011. Insecticide resistance in Aedesaegypti populations from Ceara, Brazil. Parasit Vectors.4: 5.

Masotti V, Jong LD, Moreau X, Rabier J, Laffont-Schwob I \& Thie'ry A. 2012. 
Larvicidal Activity of Extracts From Artemisia Species Against Culexpipiens L. Mosquito: Comparing Endemic Versus Ubiquist Species for Effectiveness. Comptes Rendus Biologies. 335: 19-25.

Murugan KP, Mahesh Kumar, Kovendan K, Amerasan D, Subrmaniam J \&. Hwang JS. 2012. Larvicidal, Pupicidal, Repellent and Adulticidal Activity of Citrus Sinensis Orange Peel Extract Against Anopheles stephensi, Aedesaegypti and Culexquinque fasciatus (Diptera: Culicidae). Parasitol Res, 111: 1757-69.

Mya MM, Oo NN, Ha T, Oo AW, Htay TM, New CT, S. Thaung, Y. M. M. Maung, 2016. Larvicidal effect of Artemisia vulgaris Leaves, Flower and Leaves Essential Oil Extracts Against Aedes aegypti larvae. Journal of Biological Engineering Research and Review. 3(2): 25-34.

Panneerselvam C, Murugan K, Kovendan K \& Kumar MP. 2012. Mosquito Larvicidal, Pupicidal, Adulticidal, and Repellent Activity of Artemisia nilagirica (Family: Compositae) against Anopheles stephensi and Aedesaegypti. Parasitol Res. 111: 2241-2251.

Ramkumar G, Karthi S, Muthusamy R, Natarajan D \& Shivakumar MS. 2015. Insecticidal and Repellent Activity of Clausenadentata (Rutaceae) Plant Extracts Against Aedesaegypti and Culexquinque fasciatus mosquitoes (Diptera: Culicidae). Parasitol Res, 114: 1139-44.

Samuel PP \& Tyagi BK. 2006. Diagnostic Methods for Detection \& Isolation of Dengue Viruses from Vector Mosquitoes. Indian J Med Res. 123: 615-628.
Sayono S., Hidayati AP, Fahri S, Sumanto D, Dharmana E, Hadisaputro S, Asih PBS \& Syafruddin D. 2016. Distribution of Voltage-Gated Sodium Channel (Nav) Alleles among the Aedesaegypti Populations In Central Java Province and Its Association with Resistance to Pyrethroid Insecticides. PLoS One.11:150577.

Subsuebwong T, Attrapadung S, Potiwat R \& Komalamisra N. 2016. Adulticide efficacy of essential oil from Piper retrofractum Vahl against Aedesaegypti and Culexquinque fasciatus. Tropical Biomedicine 33(1):84-87.

Sundararajan B \& Kumari BDR. 2017. Novel Synthesis of Gold Nanoparticles Using Artemisia vulgaris L. Leaf Extract and Their Efficacy of Larvicidal Activity Against dengue fever vector Aedesaegypti L. J Trace Elem Med Biol, 43: 187-196.

Tabanca N, Demirci B, Blythe EK, Bernier UR, Ali A, Wedge DE, Khan IA, Başer KHC. 2011. Composition of Artemisia abrotanum and A. Pontica Essential Oils and Their Repellent Activity against Aedesaegypti. Planta Med,.77: 52.

Wuliandari JR, Lee SF, White VL, Tantowijoyo W, Hoffmann AA \& Endersby-Harshman NM. 2015. Association between Three Mutations, F1565C, V1023G and S996P, in the Voltage-Sensitive Sodium Channel Gene and Knockdown Resistance in Aedesaegypti from Yogyakarta, Indonesia. Insects. 6: 658-85. 
